Historic, Archive Document

Do not assume content reflects current scientific knowledge, policies, or practices. 

MAY 马- 1916

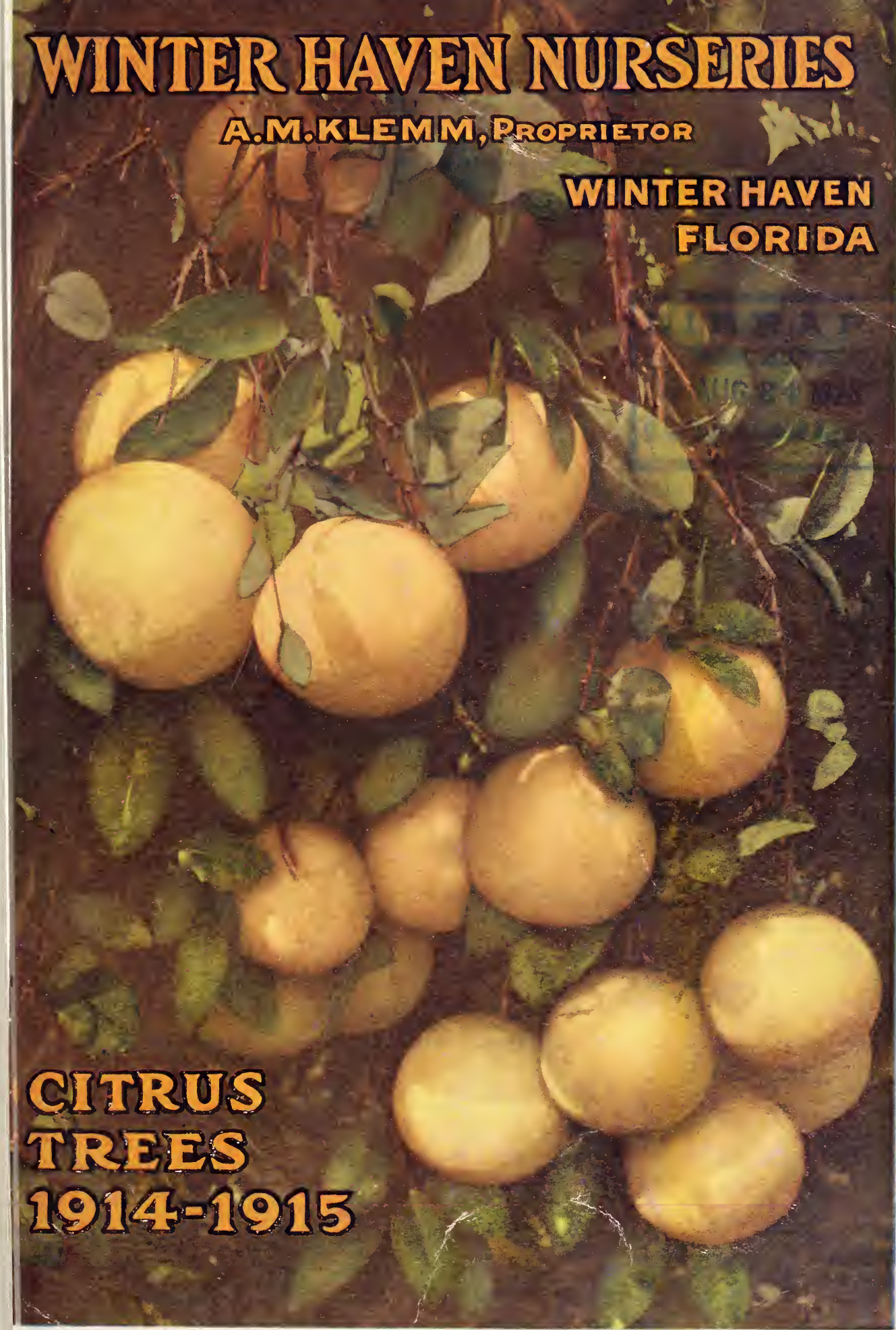


${ }^{1}+1+1=\therefore 5$ 

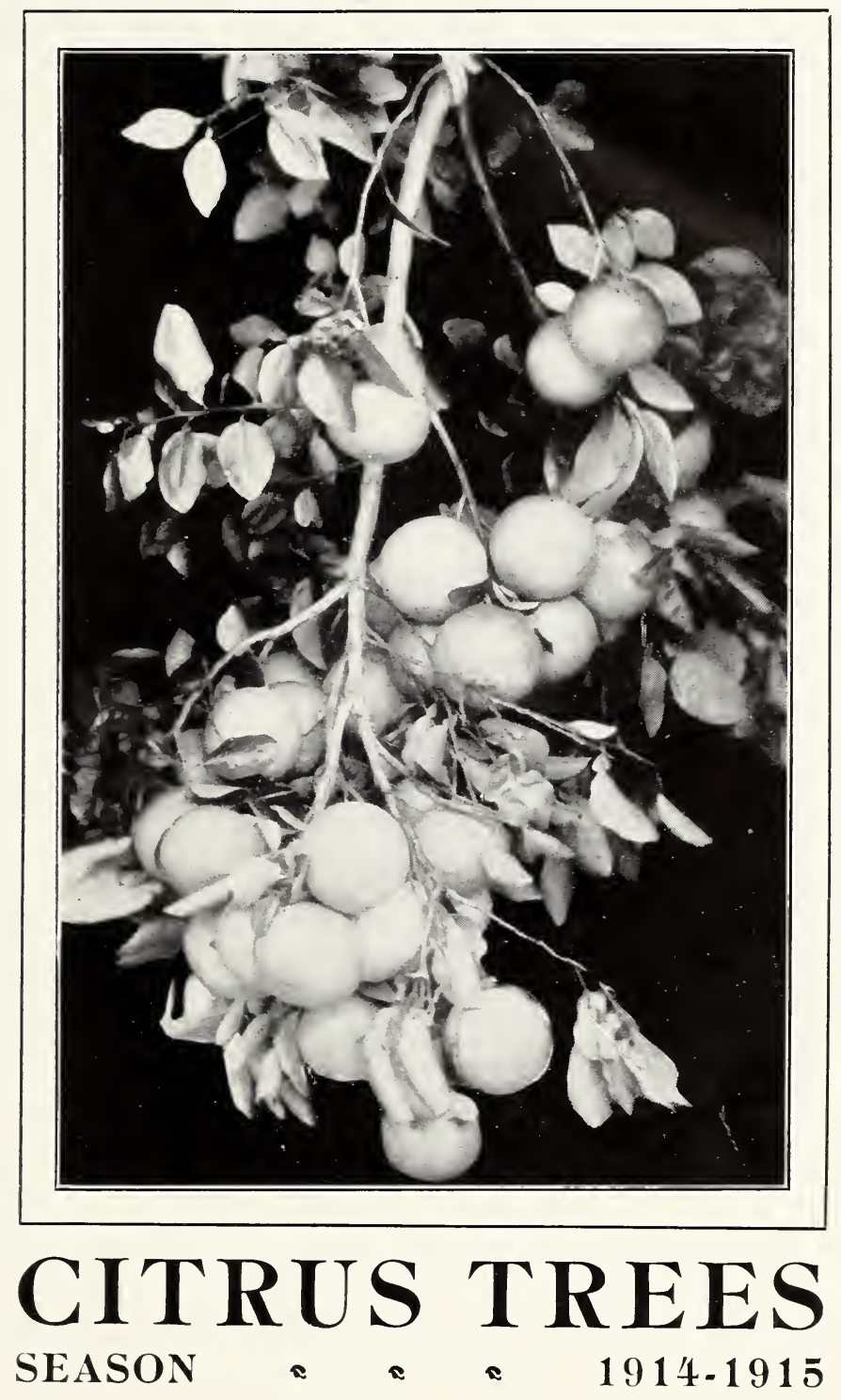

Winter Haven Nurseries A. II. KLEMM, Proprietor

W I N T E R II A V E N, F I O O R I D A 


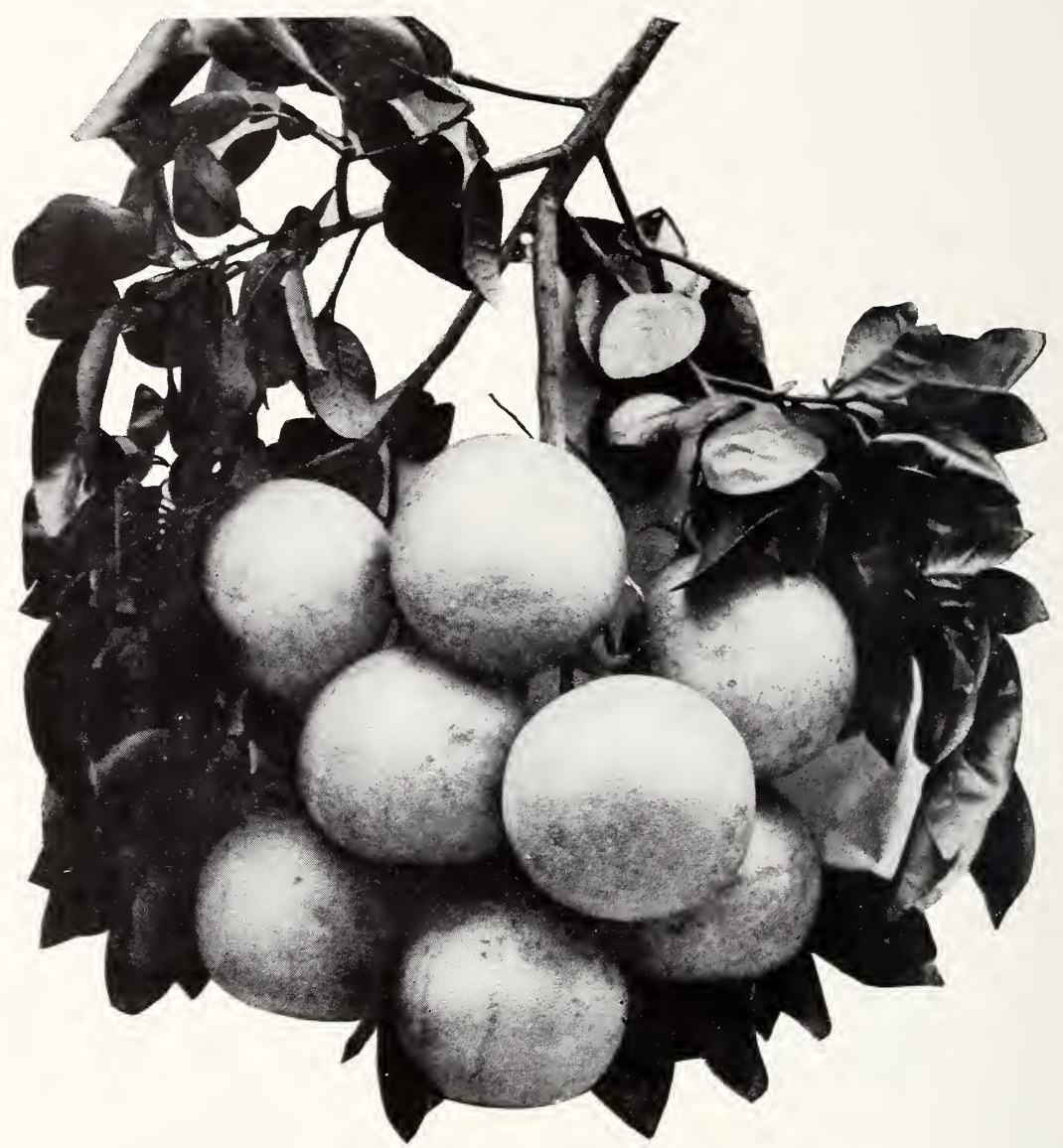

Klemm's Silver Cluster Grape Fruit 


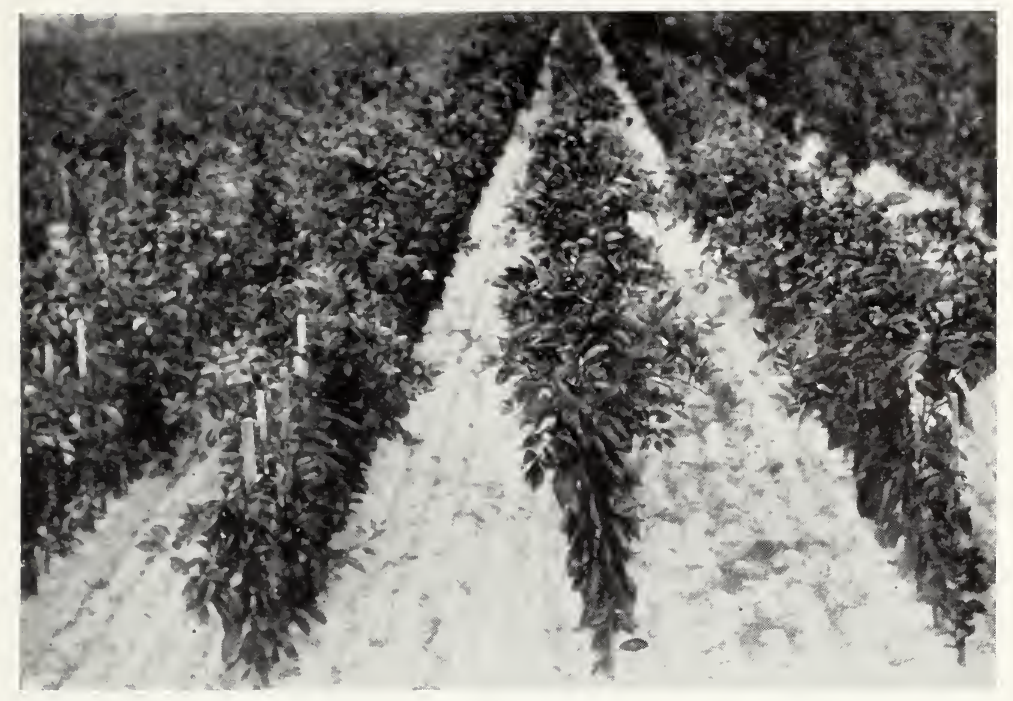

\section{First Consideration}

B

EFORE purchasing nursery stock, it is of first importance to know who and what is behind the nursery, and to know the knowledge and experience of its proprietor or proprietors.

A. M. Klemm, proprietor of the Winter Haven Nurseries, has spent a life-time in this work. Thirty-two years raising citrus nursery stock in Polk County, Florida. Before that he was for years foreman of the United States Propagating Gardens in Washington, D. C.

Any citrus fruit grower in the State of Florida knows that a Klemm tree is grown right, and its cultivation has been right, that it has neither been forced nor stunted, and that Klemm's trees can be depended upon; that in his catalogue he makes a simple, plain statement of facts. He quotes honest prices; he has his own bearing groves from which all his nursery stock is budded, and he does not bud from trees unless they are true to name and type and prolific bearers.

The fact that some of the best known and best paying groves in Florida, such as Diamond G. Koplin grove at Florence Villa, and most of the groves in the Winter Haven 


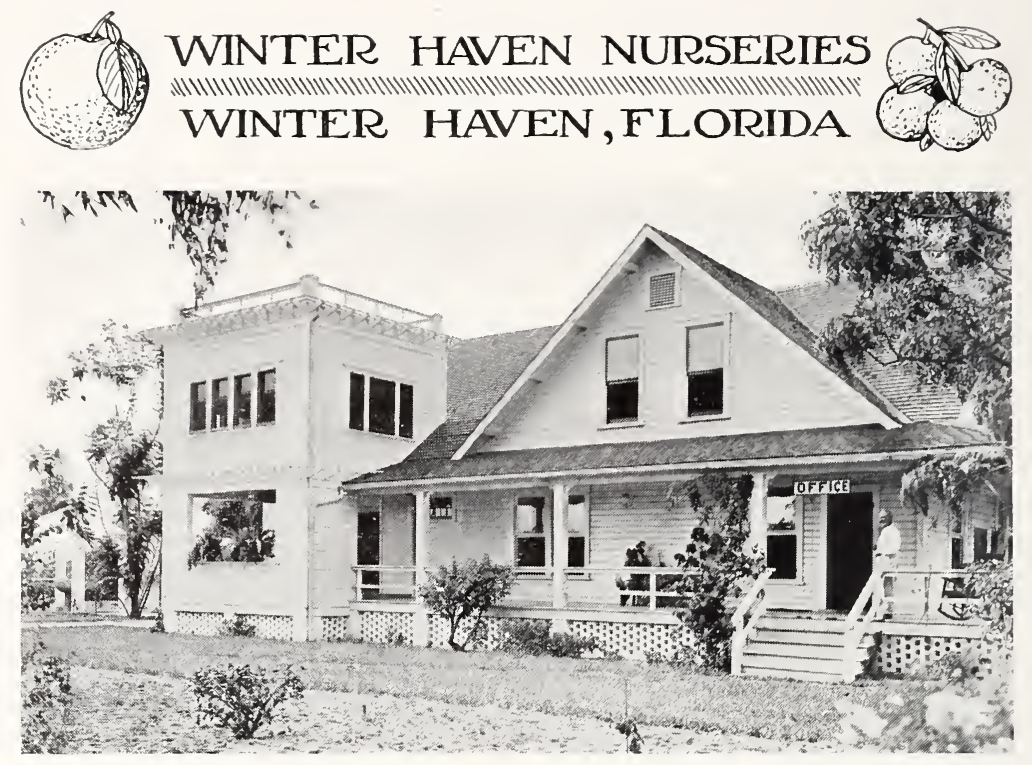

Office Winter Haven Nurseries

and Florence Villa section, are planted from Klemm's nursery stock, is evidence that he produces quality trees.

Klemm trees are to be found in the Heitman groves, in the Flowery and in the Raymond groves, and in many other well known groves in the Fort Myers section, and throughout the entire citrus belt of Florida; and the hundreds of thousands of bearing trees in the State of Florida that come from the Winter Haven Nurseries are the best indorsement for them.

The Winter Haven Nurseries have not given trade names to a fruit tree, and announced and advertised it as something different, but confine its statements to facts; its propagation to trees that are proven by experience to be profit-makers, and give to the purchaser of citrus fruit stock thirty-two years of careful selection, and recommend a few test varieties which have proven money makers to growers.

All trees put out by the Winter Haven Nurseries are their own indorsement; with clean, vigorous root system, grown in soil best adapted for producing citrus nursery stock that insures the best results when transplanted.

Every tree put out by this nursery is budded under the personal supervision of the proprietor, and everything about 


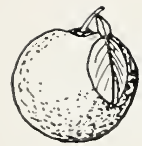

\section{WINTER HAVEN NUTSERIES WINTER HAVEN, FLORIDA

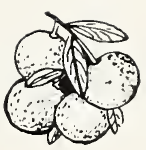

the nursery, from the planting of the seed to the shipping of the tree, is done under his personal care. His home is at Winter Haven, his entire time is given to the care of his groves and nurseries, of which he is justly proud. He does not care to enlarge his operations beyond a limit where he cannot give it his personal attention.

This is an insurance to the purchaser of Klemm nursery stock of quality, honest treatment and satisfactory dealings, and when the trees come to bearing, a paying grove, true to name and description.

When the last word is said "The inducements Klemm offers for your business are": "Price, Quality, Service."

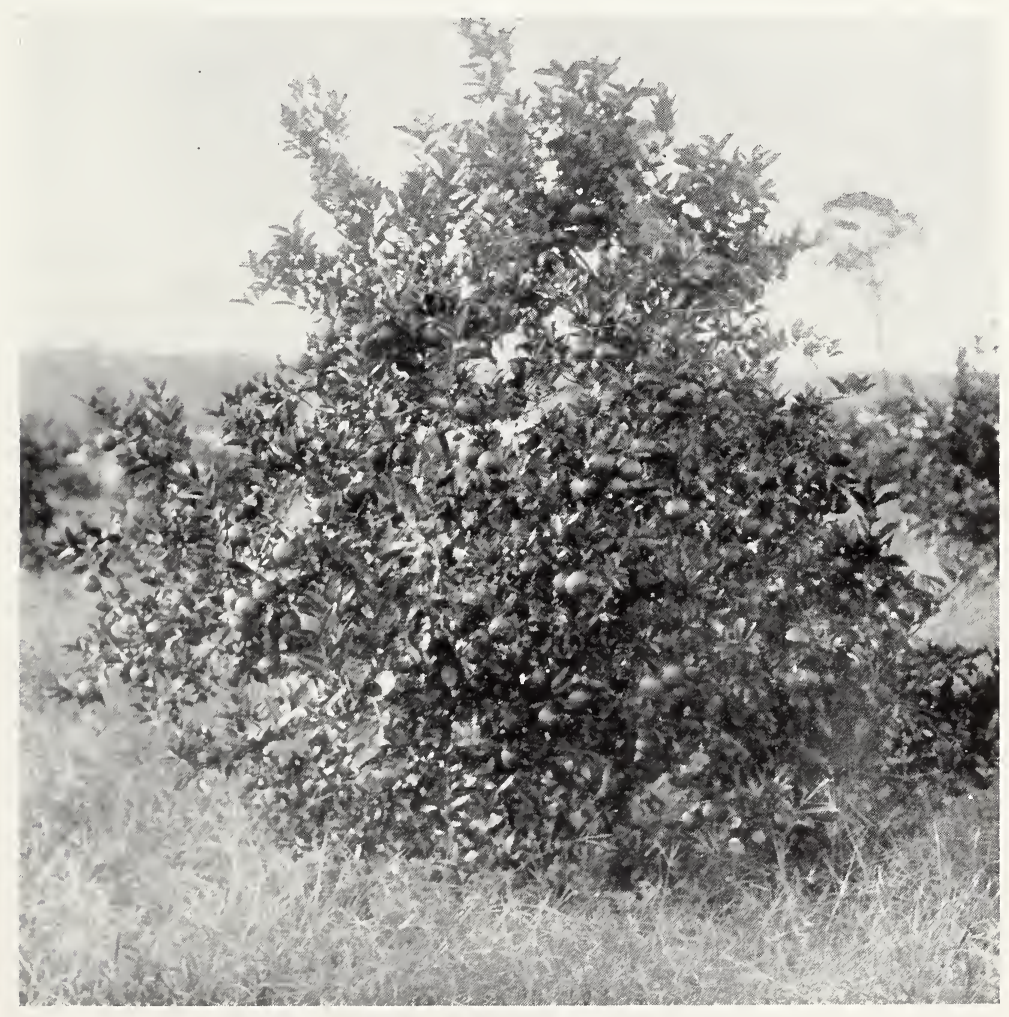

Valencia 0range Trees - four years old 


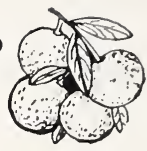

\section{COST AND PROFIT OF A GROVE}

What will it cost and what will it pay to have an Orange and Grape Fruit Grove in Florida? are the questions of prospective investors and settlers, and they want a fair, intelligent estimate, not overdrawn nor exaggerated, from a reliable man who has planted groves and reaped the harvest.

Estimates differ greatly, owing to locality, distance from town and shipping points, prices of land, labor and supplies. Following figures may apply to the pine lands in the neighborhood of Winter Haven:

1ST YEAR: Cost of 10 acres land . . . . . . . . \$1000.00

Clearing and plowing ........ 250.00

700 first class trees, $75 \mathrm{c} \ldots \ldots . .525 .00$

Planting, $10 \mathrm{c} \ldots \ldots . . . \ldots 0$

Fertilizing 3 times, $1 \mathrm{lb}$. each _ $\quad 40.00$

Labor and care ............ 150.00

2ND YEAR: Fertilizing 3 times, 2 lb. each . $\$ \$ \$ 0.00$

$\$ 2035.00$

Labor and care ........... 150.00

3RD YEAR: Fertilizing 3 times, 3 lb. each . $\$ \overline{120.00}$

Labor and care .......... 200.00

4TH YEAR: Fertilizing 3 times, 5 lb. each . $\$ \overline{160.00}$

Labor and care .......... 250.00

5TH YEAR: Fertilizing 3 times, 5 lb. each . $\$ 200.00$

Labor and care ........... 300.00

At the end of the third year some fruit will show up. At the fourth year a box or a box and half of fruit can be picked from a tree, which will pay the expenses of that year. In the fifth year, the crop will not only pay expenses, but will leave a satisfactory surplus. After the fifth year the crops will increase in quantity and quality, and from $\$ 500.00$ to $\$ 1000.00$ per acre profit per annum net to the grower is a conservative estimate; and often the groves from which the Klemm trees are budded have exceeded this many times. The better the care and cultivation, the better the results. Citrus fruit raising is a profitable business under careful attention and intelligent management. 


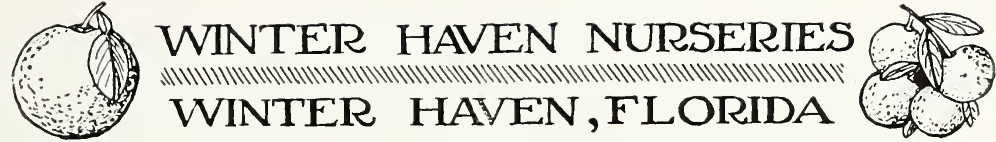 To Customers}

\section{LOCATION OF OUR NURSERIES AND GROVES}

For thirty-two years we have been in Polk County; for twenty-two years we have been at Winter Haven, where the soil is particularly adapted to the growing of nursery stock. The soil is a deep, sandy loam which produces vigorous, healthy roots and a splendid fibrous root system. And it is this soil in which our trees are grown, that gives them a right start and permits our trees being transplanted to any soil in Florida with the assurance that with the right care they will live and thrive and make heavy producers.

\section{KIND AND QUALITY OF STOCK}

We grow trees upon rough lemon, sour orange and grape fruit stock. Trees budded to rough lemon stock adapted for high land will grow up fast and make a quick showing, but their fruit not the best keeping qualities. Low and heavy lands should be planted with trees budded to sour orange and grape fruit stock; they are at home

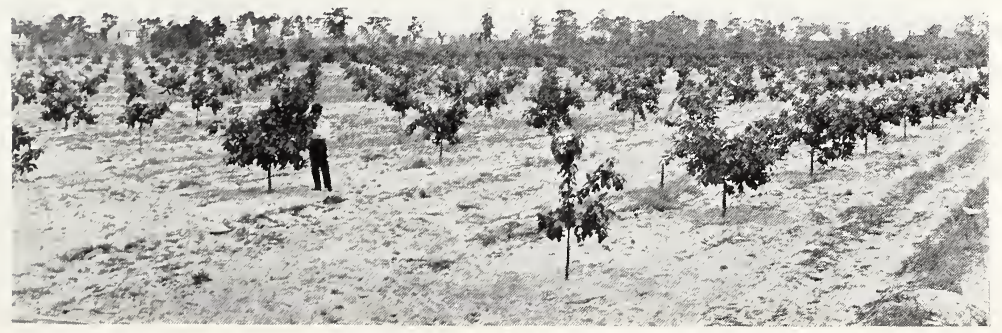

Fifteen-months-old Valencia Late Orange Grove, Winter Haven, Fla. 


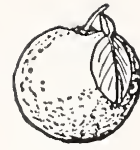

\section{WINTER HAVEN NURSERIES WINTER HAVEN, FLORIDA}

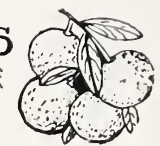

there, will develop rapidly and bear an abundance of the finest fruit which will hang on trees in prime marketable condition for a reasonable time. Any prospective purchaser writing us a description of his soil and location will, without charge, be advised as to the best to select. Each have their virtues.

Our trees are grown to stakes, buds are inserted close to ground, and the buds are taken from our own bearing trees, and we take great care that the buds are taken from our heaviest bearing trees, thus giving an insurance to the planter that he is getting a tree which will be the best of its kind.

We guarantee that our stock is free from insect pests or diseases, and there is no white fly in our Nurseries. Certificate of inspection of the State is furnished with every shipment.

\section{OUR GUARANTEE}

We give what no other nursery in the State gives-an absolute guarantee that our trees are true to name; that if you buy from us a Valencia Orange, it will not prove to be something else. That four years hence when the tree is in bearing, you will not meet with disappointment by reason of an error; that the buds inserted in our trees are from bearing trees that will produce citrus fruit trees of quality under proper care, management and conditions.

\section{PACKING}

Thirty-two years of experience has taught us how to pack trees in the best possible manner, either in bales or boxes, according to the size of order and distance of shipment, and our trees can be sent with safety to any part of the United States or to foreign countries.

Our trees are dug from the nursery with care; they are kept damp and not allowed to dry out or to receive an injury before shipment, and our packing material is the best. And for packing we make no charges. 


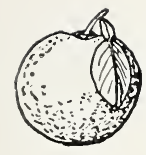

\section{WINTER HAVEN NUTSERIES \\ WINTER HAVEN, FLORIDA

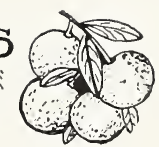

\section{OUR PRICES}

The prices of our citrus fruit trees depends upon the size, the quality of stock and the variety of fruit. We grade our citrus stock by caliper, measurements being made one inch above the bud. Our two to three feet size caliper, $\frac{3}{8}$ to $\frac{1}{2}$ inch. Our three to four feet, $\frac{1}{2}$ to $\frac{5}{5}$ inch; our four to five, $\frac{5}{8}$ to $\frac{3}{4}$ inch; our five to six, $\frac{3}{4}$ to 1 inch; our five to seven, 1 to $1 \frac{1}{t}$ inches. The prices which we quote are for the trees packed and delivered on the cars ready for shipment at Winter Haven.

The prices which we quote in this catalogue are fair and reasonable, and give a fair return for the investment and labor, and this is all that we ask and all that we believe any man is entitled to. And the fact that our prices are lower than the prices of other concerns is not an indication that they are not the equal or superior of any other stock offered.

We will meet competition on any score.

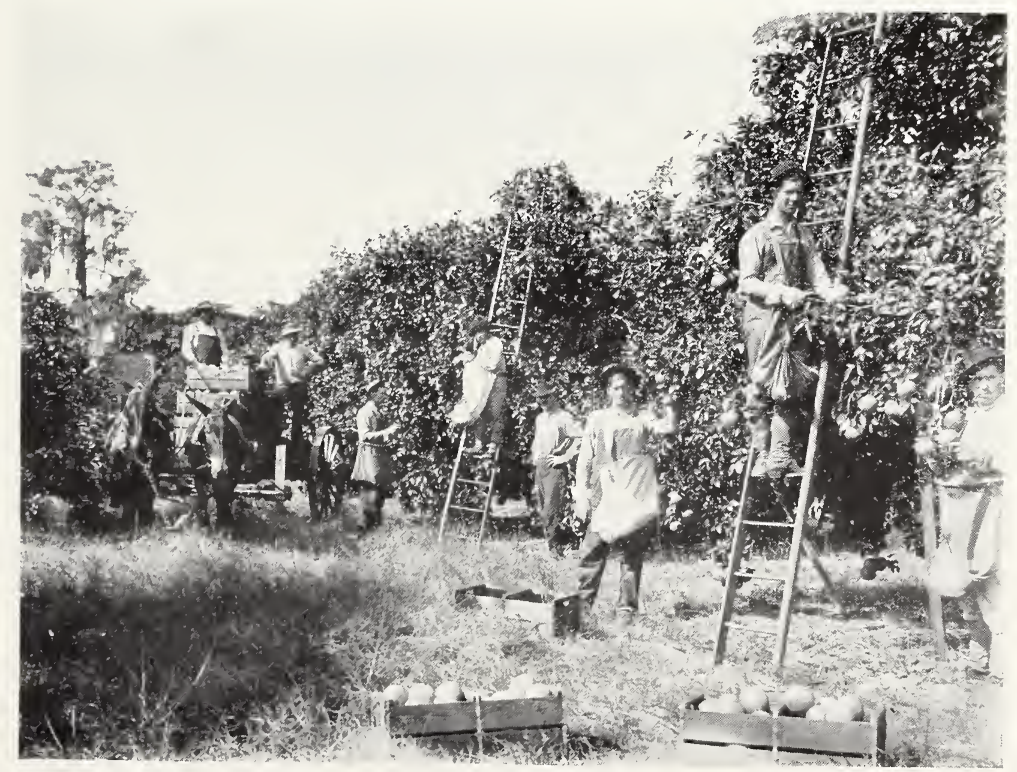

Klemm's Silver Cluster Grape Fruit Grove fifteen years old 40 to 45 boxes pər tree 


\section{THE AGE OF OUR TREES}

Our stock is kept one year in the seed bed. It is transplanted to the nursery rows and there remains for two years. Our buds are then inserted and they are left in the nursery rows one or two years. So that when you buy our trees, one-year buds, you have a tree that is four years old. When you buy our two-year buds, you have a tree that is five years old. This is one year older than many nurseries supply, and insures a quicker growth because the root system is there to support and to nourish.

\section{WE WELCOME INVESTIGATION}

All intending purchasers of nursery stock are urged to visit Winter Haven, to inspect our groves from which our stock is budded; to inspect our nurseries; to watch our packing. And those who do this will plant Winter Haven Nursery trees. For there is no better care given to a nursery than we give to ours, and the trees themselves show it.

As to our responsibility, we court the closest investigation. Our nurseries and groves, covering 250 acres, are at Winter Haven. We are known there. Investigation will be a simple matter.

\section{OUR TERMS}

By reason of the fact that we sell our nursery stock at the most reasonable prices, consistent with quality, we have established a rule that where trees are ordered for immediate delivery, payment must accompany the order; those persons desiring to insure securing their stock and getting the best selection from the nursery, and who order their trees for future delivery, can pay twenty-five per cent with the order, and the balance when they order the trees shipped. Remittance may be made by bank draft, post office or express draft.

\section{PREPARING OF THE LAND}

The land should be cleared of all trees, well plowed and harrowed, and if this can be done in time, planted to cow- 


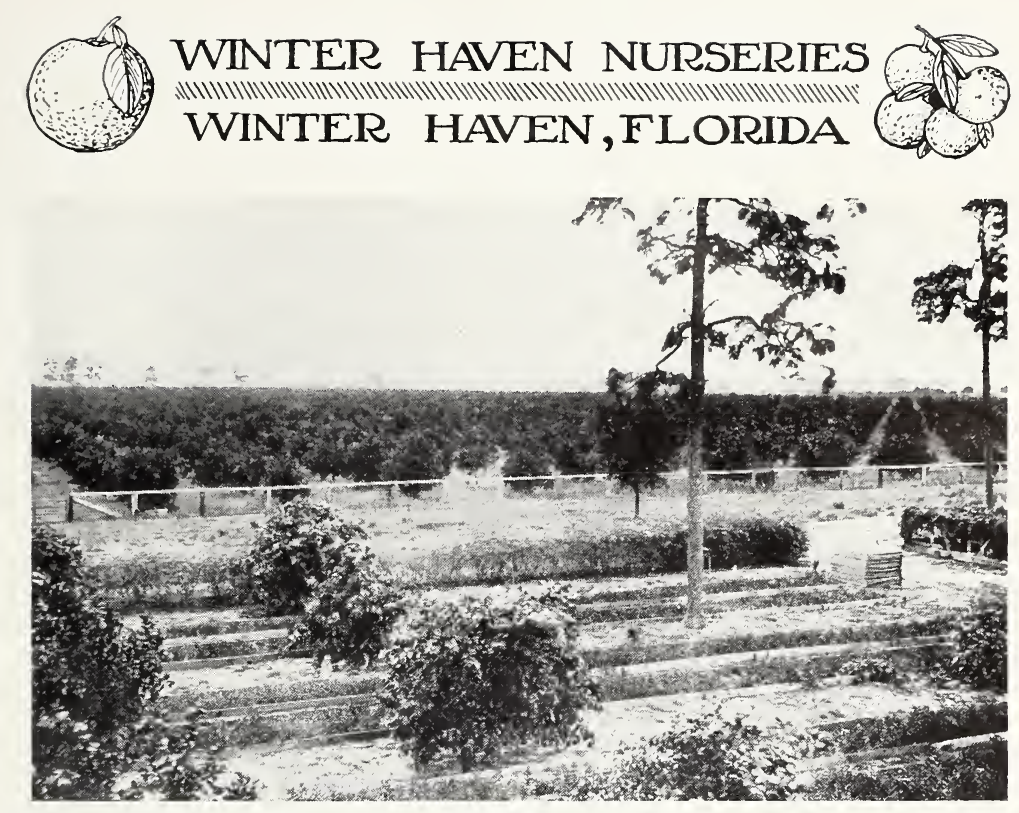

Fifty-Acre Orange Grove

peas or velvet beans, to be plowed under in fall. This will sweeten and mellow up the soil, and add humus. After the land is thoroughly prepared, it should be lined off for the tree rows and stakes set where the trees are to be planted.

\section{DISTANCE OF THE TREES}

On rich hammock land trees should be planted 30 feet apart; on pine land, such as we have at Winter Haven, 25 feet apart, we found the most satisfactory distance, or 70 trees to the acre. Square planting we found most convenient, as it will permit the working of the trees in every direction. Some planters are setting their trees 20x30 feet, which is a good distance too; everyone may suit himself in that direction.

\section{PLANTING OF THE TREES}

Distribution of trees to the places of planting in advance of actual setting, exposing the roots to sun and wind, is a pernicious practice. Take the trees as you need them from the package in which they arrived, wet the roots well, wrap them up into a damp covering, from which remove them at planting. 


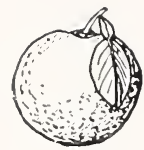

\section{WINTER HAVEN NUTRSERIES WINTER HAVEN, FLORIDA

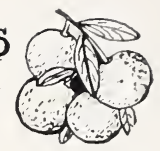

Holes about 4 feet wide should be dug, placing the top soil aside for further use. Place across the hole a 5-foot strip, notched on middle to show the place of stake and center of hole, place tree straight into hole, working top root into opening of stake, and trunk fitting the notch on side of planting board, the dirt line on tree just on under side. This will place tree just at the right position, not too high nor too low. More trees fail to grow on account of too deep planting than from other causes.

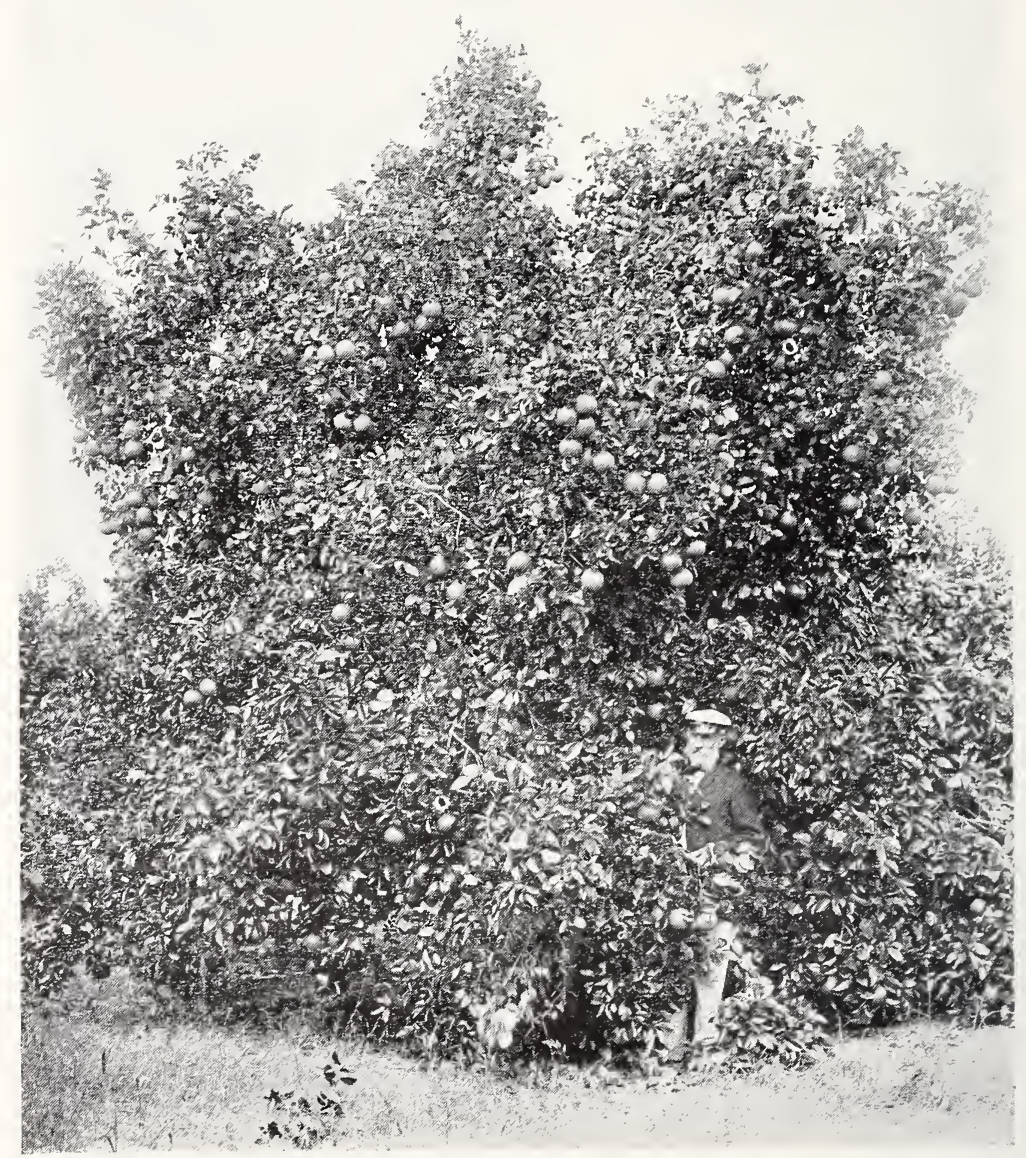

Klemm's Silver Cluster Grape Fruit Tree 
Spread out roots well into natural position, don't let them bunch in a mass against the top root; cover well with top soil laid aside before, working soil well around the roots; apply a pail or two of water, which will settle the soil well amongst the roots, then fill up soil to the level of hole. Tramp down well and evenly, holding the top of tree straight, sprinkle a pound of good tree grower or vegetable fertilizer around the tree, working it into ground slight1y. Do not mix any fertilizer into the hole, with the soil used for covering roots. It may burn the tender roots and injure or kill the tree.

After planting is finished, draw soil around the tree into a bank about 4 inches high and 4 feet wide; it will keep the ground cool and the roots moist.

If weather is dry and hot, trees should be watered every 10 to 14 days, or as often as they show the need of water. Remove the soil around the trees, forming a basin about 3 feet wide, apply a pail or two of water and replace the soil. This should be continued until the rainy season takes care of tree, when the bank around the tree should be leveled. Another pound of fertilizer may then be applied.

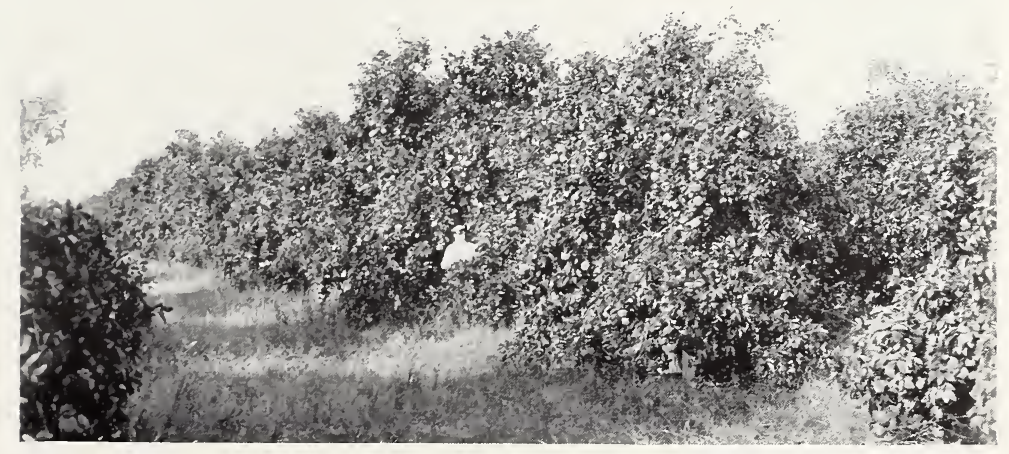

Klemm's Silver Cluster Grape Fruit Grove 


\section{WINTER HAVEN NURSERIES
MINT)
WINTER HAVEN, FLORIDA Description of Varieties}

\section{POMELO OR GRAPE FRUIT}

Silver Cluster. “Klemm's." Size medium to large, will pack forty-six to sixty-four to box. Color light yellow; form flattened, base smooth, stem thick. Bitter principle

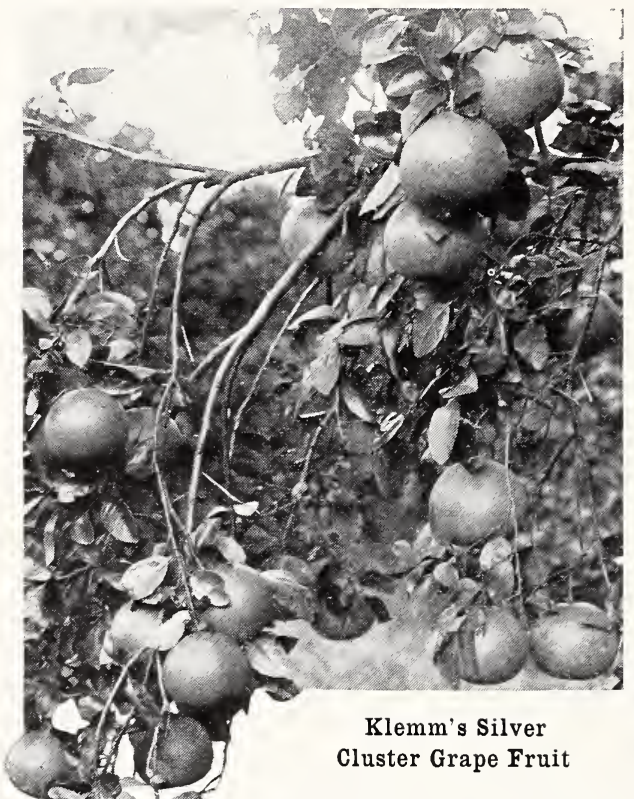

well developed, acidity and sweetness well blended; juice almost transparent. Quality of the very best and unsurpassed by any other Grape Fruit offered by the trade. Fruit ready for the holiday trade, is an excellent keeper and will hang on trees throughout the season until summer, improving in quality. The tree is a very strong, vigorous grower, and an early and heavy bearer, carrying its fruit well throughout the season. Fruit well distributed all over and inside of the tree. It has proved the hardiest of all varieties of Grape Fruit and has become a favorite and money maker wherever planted. The famous Diamond G. Koplin grove at this place is planted in Klemm's Silver Cluster Grape Fruit trees from our nurseries, also many more of the well known and best paying groves in this vicinity and all over the State.

Klemm's Silver Cluster Grape Fruit received the highest award at the St. Louis Exposition and at the Tampa Fairs. 


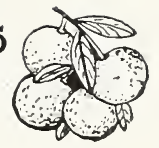

The parent tree from which we propagated our stock was planted here twenty-two years ago, and is still here bearing heavy crops.

\section{TESTIMONIAL}

United States Departient of Agriculture, Bureau of Plant Industries.

Ponological Collections.

Washington, D. C., June 6, 1910.

Mr. A. M. Klemm,

Winter Haven, Florida:

DEAR SIR:

Your letter of May 17th, and the box containing specimens of Klemm's Silver Cluster Grape Fruit or Pomelo, came duly. I have secured a very fine painting of this pomelo for placing on record in this office.

The pomelo is of excellent quality and fine appearance, and I am much pleased with it. Thank you for your courtesy in sending it.

Yours very truly, G. W. BRACKETT, Pomologist.

Marsh Seedless. Size medium. Will pack fifty-four to sixty-four to the box. Slightly flattened, thin rind. Bitter principle not strongly marked. Nearly seedless. Fruit juicy and of good quality. Tree a good grower and regular bearer. Originated near Lakeland, Fla.

\section{ORANGES}

\section{EARLY VARIETIES}

Parson Brown. One of the best early varieties. The fruit is ripe and sweet in October, even before colored; is slightly oblong, has a smooth, thin skin and is a good shipper. The tree is very thorny, grows to a large size and is a prolific bearer.

Ruby Blood. An excellent early variety. The fruit is of medium size, nearly round; rind thin but tough; pulp melting, rich, juicy. As the fruit ripens it becomes mottled and streaked with blood red; often the entire pulp colors 


\section{WINTER HAVEN NURSERIES}

WINTER HAVEN, FLORIDA

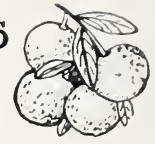

ruby red, showing through the skin a reddish blush. The tree is a good grower, thornless, and an early and prolific bearer.

\section{MID-SEASON VARIETIES}

Pineapple. A most excellent variety and the best Orange grown in Florida. Fruit of medium size, skin thin and tough, flesh juicy, flavor vinous, quality unsurpassed. It is an excellent shipper and good keeper on the tree, which is a most vigorous grower, and an early, regular and heavy bearer. We recommend this variety highly for general planting.

Dancy Tangerine. The best mid-season variety of the Mandarin family, or kid glove orange. The fruit is flattened, with a thin, aromatic skin of a deep, glossy red color. The skin is easily detached from the pulp, which is very juicy, spicy and of excellent quality. The fruit is very showy, making a fine appearance in the market, and therefore always brings a good price. The tree is a good grower, thornless, and very prolific.

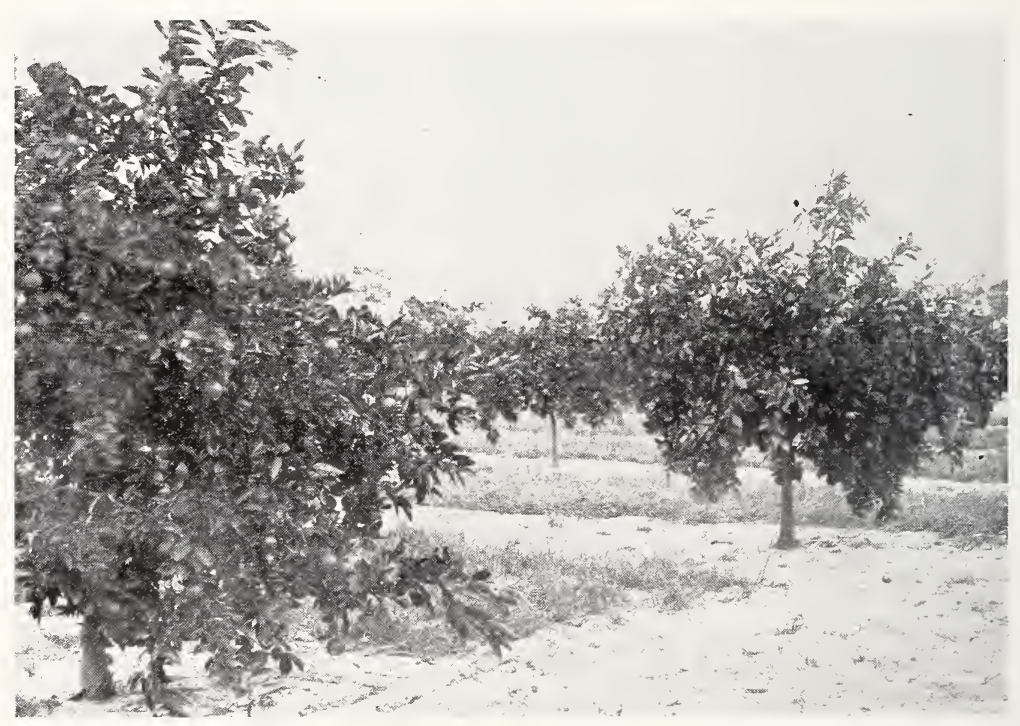

Pineapple Orange Trees -three years old 
WINTER HAVEN NURSERIES WINTER HAVEN, FLORIDA

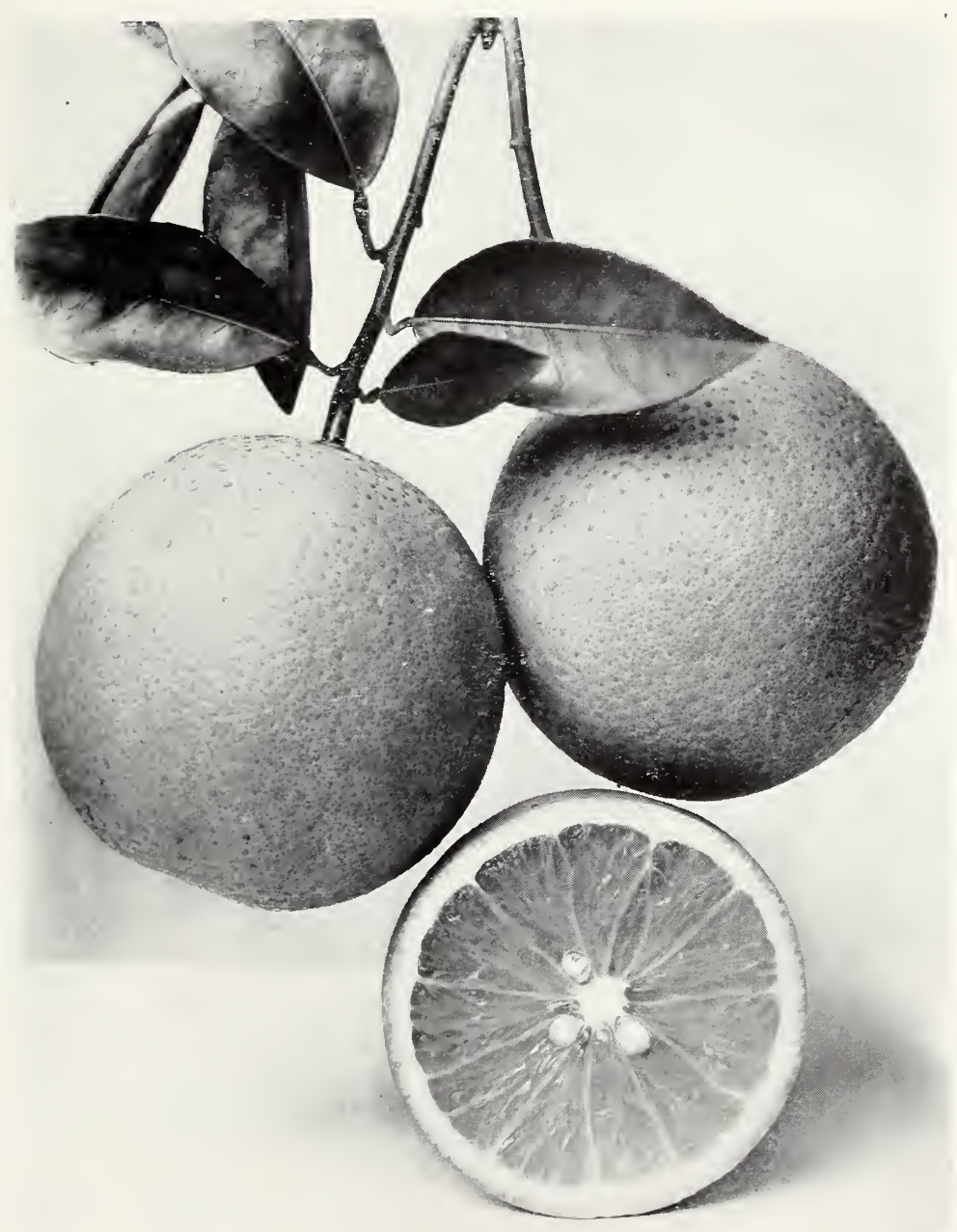

Valencia Late Orange

\section{LATE VARIETIES}

Valencia Late. An excellent late variety of superior quality, equalled only by the Tardiff, with which it shares several characteristics. Fruit of medium size, slightly oval, solid, heavy; light color. Skin rather thin and of strong texture. Flesh of deep and rich color; grain fine, firm and 


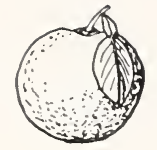

\section{WINTER HAVEN NURSERIES \\ WINTER HAVEN, FLORIDA}

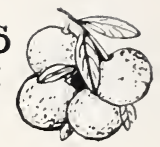

crisp; abundant juice, excellent flavor, the quality that suits the hot month. The tree is of fine, vigorous growth with few thorns. Regular and prolific bearer. Season latest, fruit maintaining its fine shipping qualities until summer.

Hart's Late or Tardiff. The best late variety. Fruit of medium size, round or slightly oval, solid and heavy. Skin thin and tough; flesh very firm, flavor brisk and racy. Few seeds. The tree is a strong, spreading and vigorous grower, very prolific; has a distinct foliage and few thorns only. The fruit ripens in April and hangs on tree in good, marketable condition until summer. "No other late orange has surpassed this variety."

King. A Mandarin variety. Very large, flattened, with loose adhering rind and segments, like all Mandarin varieties. Color orange red; skin rough but general appearance fine; juicy, meaty, its high and peculiar aromatic flavor very agreeable. Quality of the best. Tree upright, strong grower, foliage dark and rich; an abundant bearer. Season: March, April and May; keeps in good condition even later.

\section{LEMONS}

Villa Franca. The best variety for Florida. Medium size; rind thin, smooth and sweet; juicy and of fine quality. Fruit one of the best and a good shipper. Tree is a vigorous grower, very productive; has few thorns.

\section{LIMES}

Tahiti Seedless. Fine, extra smooth skin, lemonshaped, of good size. Will pack about 300 to the box. Requires no coloring; good keeper. Main crop ripens in August; some fruit all the time. The tree is most prolific in growth and bearing of any of the citrus family. The fruit has but a trace of the pronounced flavor of the ordinary lime. 


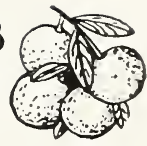

\section{KUMQUAT}

Kumquat or Kin Kan of Japan. A small fruit, about three-fourths to one inch in diameter and one inch to one and one-half inches long, much used for preserving. Fruit may be eaten from tree, and its peculiarity is the sweet skin and rather bitter flesh. The tree is of dwarfish habit, has a pretty foliage, and serves as a fine ornamental.

\section{TESTIMONIALS}

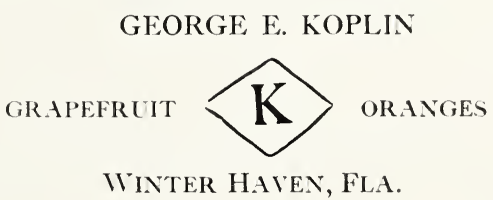

March $4,1910$.

Irr. A. II. Klemm,

Winter Haven, Fla.

My Dear Sir:

I know you will be interested in learning that the 24 Silver Cluster Grape Fruit trees I bought from you eight years ago, are the finest trees in my grove. In their fifth year I picked from the 24 trees 60 boxes grape fruit, while in their seventh year (just passed) I picked 168 boxes of good, high grade fruit from them, an average of seven boxes to a tree. They were healthy and vigorous from the start, and have shown remarkable growth.

Sincerely,

GEO. E. KOPLIN.

\section{THE QLARLES-LAIRD DEYElOPMENT COMPANY}

ST. LOUIS, Mo.

Mr. A. M. Klemm, Proprietor

March 2, 1914.

Winter Haven Nurseries,

Winter Haven, Fla.

My Dear Mr. Klemm:

Enclosed please find Quarles Laird check for $\$ 865.20$, the amount of the two bills herewith. As far as we could see, the trees which you furnished us this year were fully as good as the last year's ones, and I have no doubt they will equal if not exceed the 1913 record.

I really believe that you will have reason to be proud of our grove some of these days, and in passing, will say "Those are every one my trees",

I certainly enjoyed my visit to Winter Haven and the looking through your nurseries and groves, and hope to see you again next year.

Yours sincerely,

JOHN A. LAIRD. 


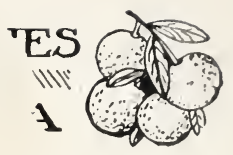

\section{The}

\section{Winter Haven Nuseries}

Winter Haven, Florida

A. M. Klem M, Prop.

\section{Price List on Trees}

\section{GRAPE FRUIT, TANGERINES AND KUMQUATS}

\begin{tabular}{|c|c|c|c|}
\hline GRADE & 10 & 100 & 1000 \\
\hline 2 to 3 feet, $3-8$ to $1-2$ inch & $\$ 5.00$ & $\$ 45.00$ & $\$ 400.00$ \\
\hline 3 to 4 feet, $1-2$ to $5-8$ inch $\ldots$ & 6.00 & 55.00 & 500.00 \\
\hline 4 to 5 feet, $5-8$ to $3-4$ inch ... & 7.00 & 65.00 & 600.00 \\
\hline 5 to 6 feet, $3-4$ to 1 inch & 9.00 & 80.00 & 750.00 \\
\hline o 7 feet, 1 to $11-4 \mathrm{inch}$ & 12.00 & 100.00 & 900.00 \\
\hline to 7 feet, $11-4$ to $11-2$ inch & 14.00 & 125.00 & 1000.00 \\
\hline
\end{tabular}

\section{ORANGES, LEMONS, LIMES}

\begin{tabular}{|c|c|c|c|}
\hline GRADE & 10 & 100 & 1000 \\
\hline 2 to 3 feet, $3-8$ to $1-2$ inch. & $\$ 4.00$ & $\$ 35.00$ & $\$ 300.00$ \\
\hline 3 to 4 feet, $1-2$ to $5-8$ inch. & 5.00 & 45.00 & 400.00 \\
\hline 5 feet, $5-8$ to $3-4$ inch & 6.00 & 55.00 & 500.00 \\
\hline 6 feet, $3-4$ to 1 inch & 7.00 & 65.00 & 600.00 \\
\hline o 7 feet, 1 to $11-4$ inch. & 8.00 & 75.00 & 700.00 \\
\hline o 7 feet, $11-4$ to $11-2$ inc & 9.00 & 85.00 & 800.00 \\
\hline
\end{tabular}

Prices F. O. B. Cars Winter aven 


\section{ORDER SHEET}

A. M. KLEMM, Winter Haven, Fla.

For amount enclosed. FOR SHIPPING DIRECTIONS

To P. 0. ADDRESS OF PURCHASER

Name

Place.

P. $O$.

County

County

Via

State

Do you want us to substitute in case any varietics or sizes crdered should be exhausted? Write yes or no

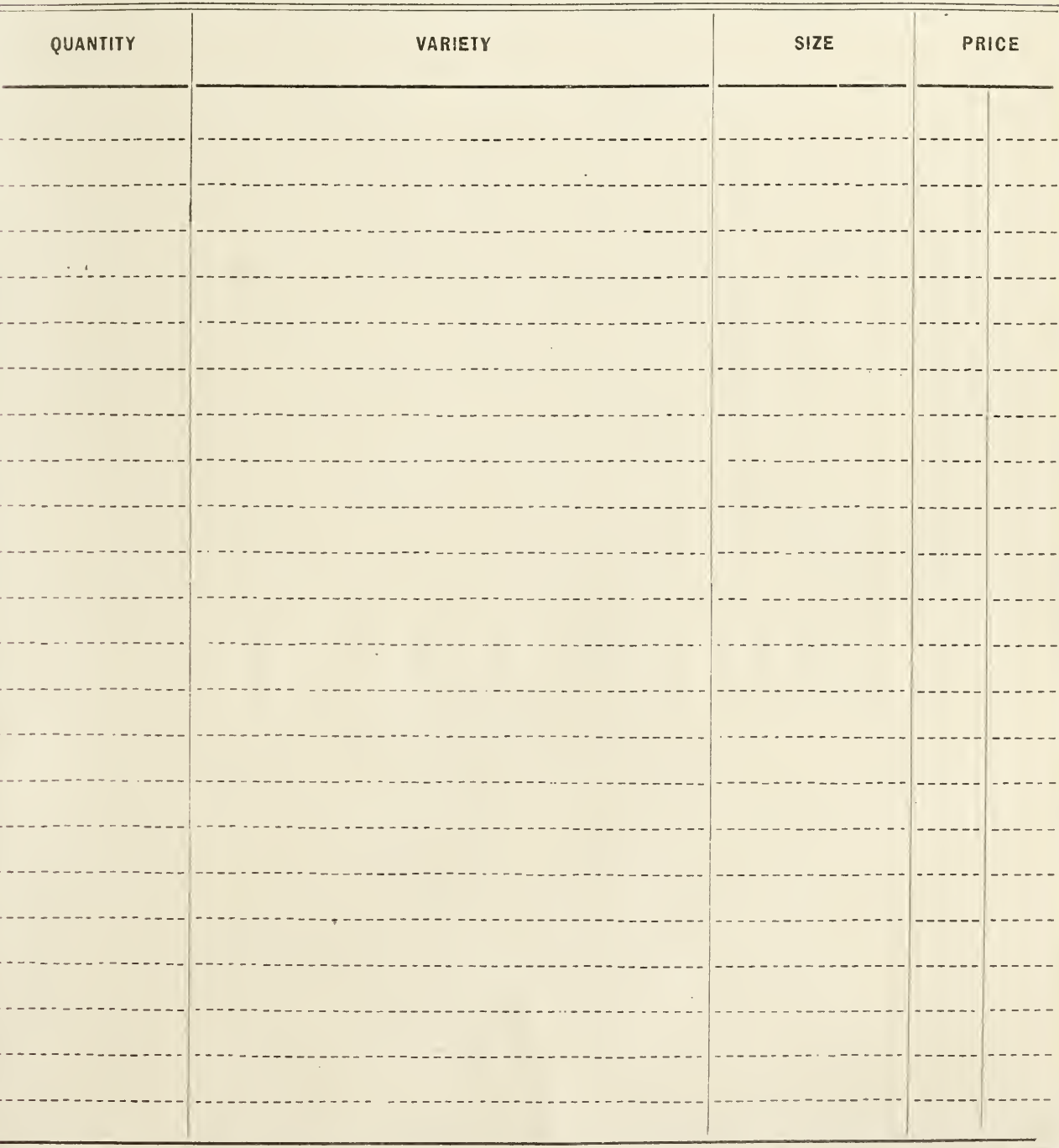




WINTER HAVEN NURSERIES WINTER HAVEN, FLORIDA 